UCRL-ID-131729

\title{
Core Testing of Zinc/Air Refuelable Battery Modules
}

\author{
J. F. Cooper \\ R. Krueger \\ R. Smith \\ F. Tokarz
}

August 20, 1998

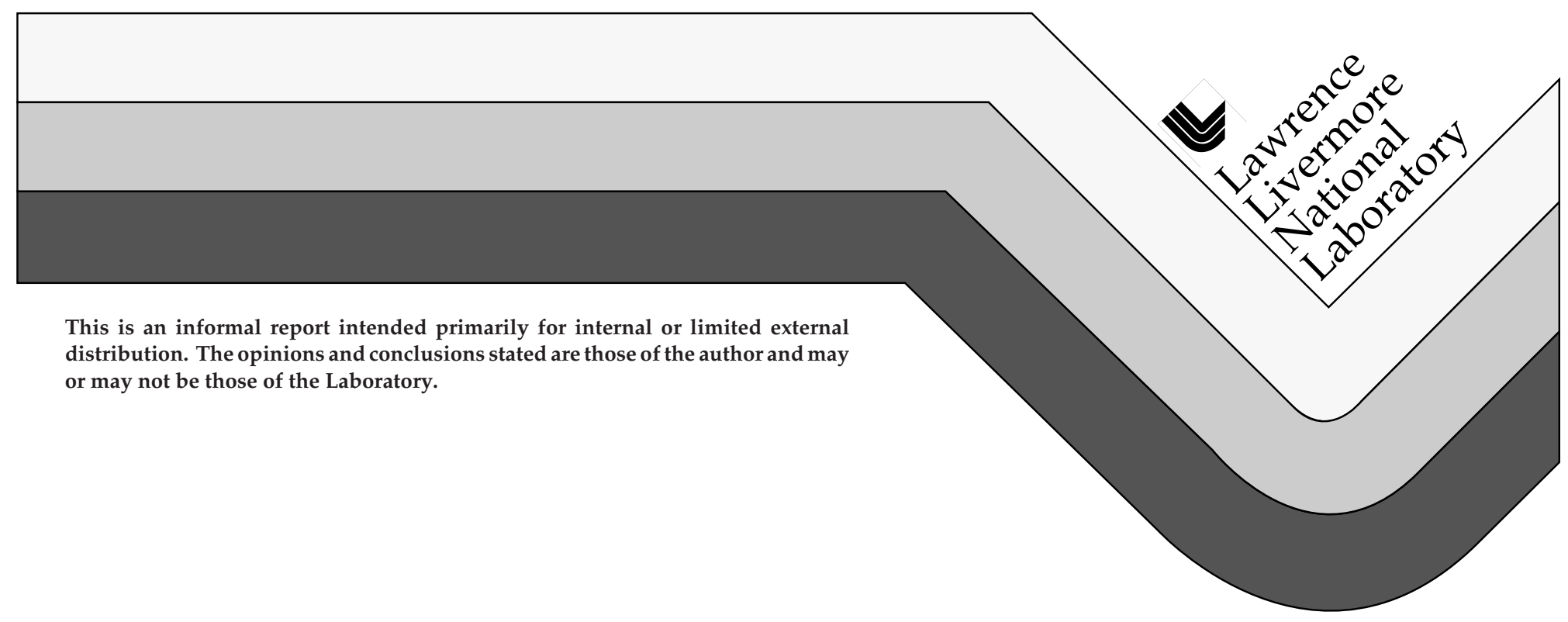




\section{DISCLAIMER}

This document was prepared as an account of work sponsored by an agency of the United States Government. Neither the United States Government nor the University of California nor any of their employees, makes any warranty, express or implied, or assumes any legal liability or responsibility for the accuracy, completeness, or usefulness of any information, apparatus, product, or process disclosed, or represents that its use would not infringe privately owned rights. Reference herein to any specific commercial product, process, or service by trade name, trademark, manufacturer, or otherwise, does not necessarily constitute or imply its endorsement, recommendation, or favoring by the United States Government or the University of California. The views and opinions of authors expressed herein do not necessarily state or reflect those of the United States Government or the University of California, and shall not be used for advertising or product endorsement purposes.

This report has been reproduced directly from the best available copy.

Available to DOE and DOE contractors from the Office of Scientific and Technical Information P.O. Box 62, Oak Ridge, TN 37831

Prices available from (423) 576-8401

Available to the public from the National Technical Information Service

U.S. Department of Commerce 5285 Port Royal Rd. Springfield, VA 22161 


\title{
CORE TESTING OF ZINC/AIR REFUELABLE BATTERY MODULES Interim Report: April - September 1997
}

by

\author{
John F. Cooper, Roger Krueger, Ray Smith and Frank Tokarz \\ Lawrence Livermore National Laboratory L-352, 7000 East Avenue, PO Box 808 \\ Livermore CA 94550 \\ Tel. (510) 423-6649; Fax 422-0049; E-mail Cooper3@LLNL.gov
}

\begin{abstract}
We are developing a refuelable zinc/air battery (6-cells) for evaluation under the five USABC "core" test protocols. In the first half of the two year project (\$100K, FY1997), an advanced refuelable design was developed, fabricated and tested at power levels up to $415 \mathrm{~W}$. . Performance matched or exceeded that of earlier multicell systems. A computer program was developed for automated data acquisition and drive cycle simulation. Small mockup cells ( 80 $\mathrm{cm}^{2}$ ) were constructed for rapid testing of components. In the follow-on effort (FY1998, \$100K) we will make minor advances in system design and fabrication efficiency, and seek to improve cathode performance and life, before delivery of two final units for test at DOE laboratory.

Background. This is a summary of work performed in the first year of a two year (FY1997-8), \$200K DOE project, sponsored by Heavy Vehicles Division. The overall goal of this project is to develop and test an advanced 6-cell module of the refuelable zinc/air battery, leading to a standardized design. Following the LLNL development and tests, two modules will be delivered to a suitable DOE test laboratory for core testing (Table 1). Specific tasks are as follows: (1) Produce a total of ten 6-cell modules of standardized and documented design. (2) Fabricate and test these modules two at a time through the first 5 tests of the USABC protocol. The first tests are a corroboration of the overall design. The second test of two modules will include improvements and minor modifications. Finally, 2 modules will be constructed and subjected to pre-delivery tests at LLNL. (3) Following tests of the 6 modules at LLNL, four addition units will be assembled: two for tests at a DOE test laboratory and two will be retained for parallel tests at LLNL.

Design and Fabrication of test modules. The advanced bipolar cell design was developed and is comprised of $0.75 \mathrm{~mm}$ reinforced epoxy plates (to support air cathodes and particulate anodes having $300 \mathrm{~cm}^{2}$ active electrode areas) and a polysulfone frame (with parallel imbedded electrolyte and air flow channels, and a chamber for containing zinc fuel pellets). The frames were milled by computer controlled machines, and the plates were rough fabricated by an electronics supplier. One face of the plate (shown in Figure 1) supports machined copper standoffs for the cathode (by solder or conductive epoxy), and the other face supports a basket containing zinc particles. The plates are clad on both sides with copper foil -- $0.0612 \mathrm{~g} / \mathrm{cm}^{2}(2$ $\left.\mathrm{oz} / \mathrm{ft}^{2}\right)$. The anode and cathode faces are electronically shorted externally with a foil union.

The multicell stack is supported on a rigid G10 frame above a 5 liter electrolyte storage tank (Figure 2). Air and electrolyte flow systems include 12 VDC pulse-controlled fans and a 12 VDC centrifugal pump, both operating at fractional specifications; these are powered by the zinc/air stack through DC/DC solid state transformers. An external electronic control box provides individual cell monitoring, polarization measurements, pump control, fusing, and power distribution to external loads. The zinc "fuel" consists of $1.0-$ or $0.75 \mathrm{~mm}$ cut wire; the electrolyte is $12 \mathrm{~N} \mathrm{KOH}$, preheated to $60^{\circ} \mathrm{C}$.

Polarization. A typical polarization curve (Figure 3) shows a high internal impedance associated with the Ohmic voltage drop through cathode and separator. An additional voltage
\end{abstract}


loss is caused by a Faraday shield effect of the expanded metal basket (Exmet, Inc.) which separates the zinc bed from the inter-electrode separator (Pal RAI, Inc) and cathode. IR losses associated with solder or Ag-epoxy bonded air cathodes are low ( $\left.\sim 0.3 \mathrm{ohm}-\mathrm{cm}^{2}\right)$; those of the copper cladding used in bipolar connections of anodes and cathodes are negligible by comparison. The multicell stack was discharged up to a power of $415 \mathrm{~W}$ (at $105 \mathrm{~A}$ ), compared with the highest power of $175 \mathrm{~W}$ obtained during the February 1995 test $^{1}$ and similar to those obtained in single cell tests. ${ }^{2}$

Status Tests of the first 6-cell module was conducted in July and of the second in September, following improvements in air-electrode current collection, in corrosion resistant coatings and in assembly techniques. The bipolar plate is currently being redesigned to allow rapid assembly using automated soldering machines and conductive epoxy cements. The electrolyte storage tank is being redesigned for minimum weight and thermal insulation. These and other improvements will be incorporated in the 3rd and 4th modules to be fabricated in early FY1998.

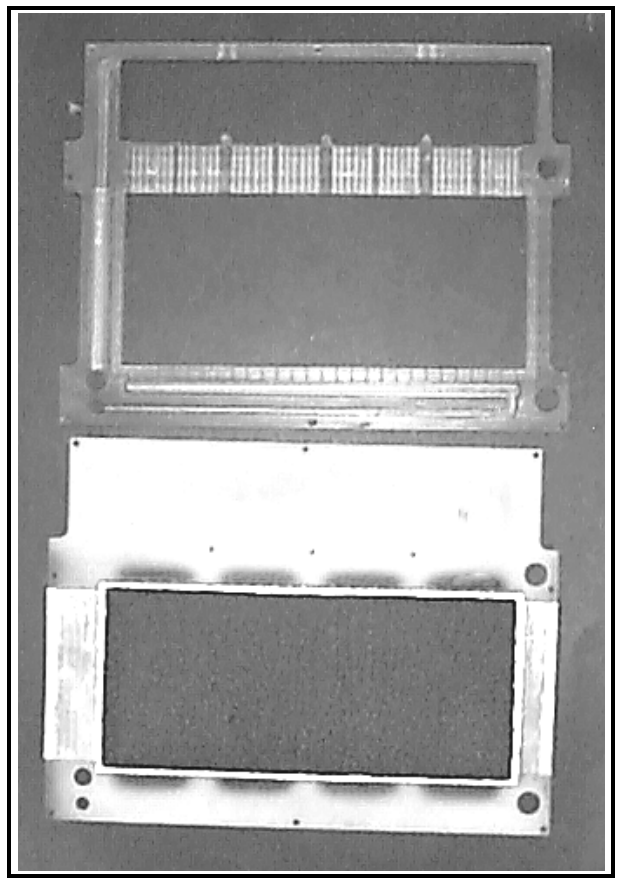

Figure 1. The cell consists of a bipolar plate (left, below) and a frame (above) containing internal electrolyte and air flow channels and a hopper. The bipolar plate is shown on the positive face, with an air electrode shown attached to the current collection frame. The smaller rectangular opening at the top of the frame forms a hopper for containing zinc pellets. These pellets are gravity fed on demand into a zinc anode current collector basket on the reverse of the bipolar plate (not shown). 


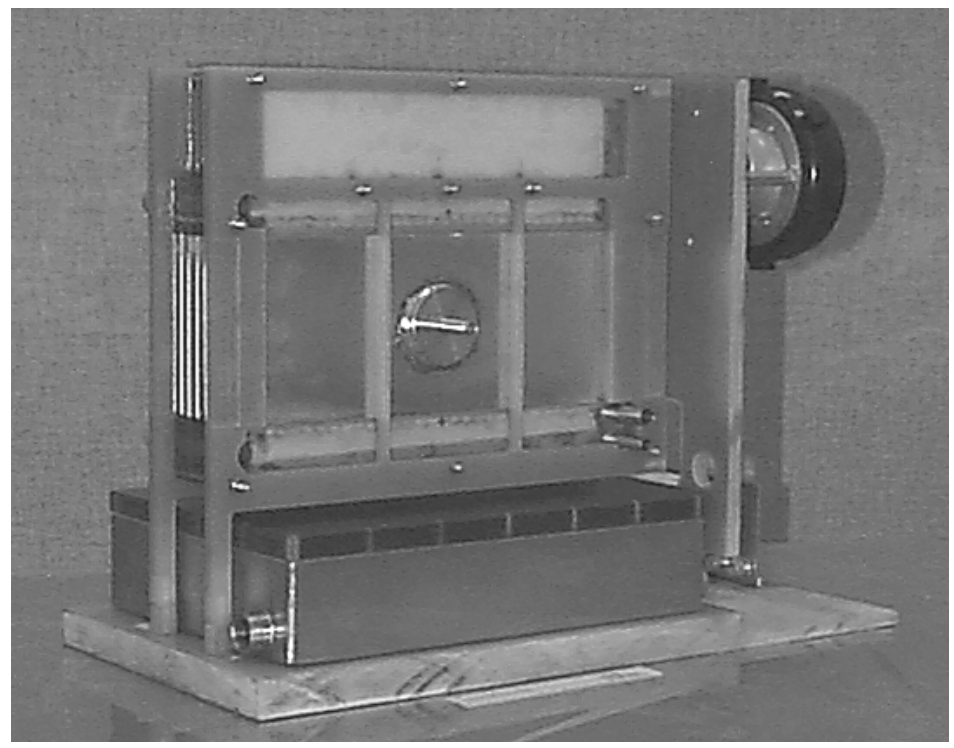

Fig. 2- First Assembled Test Module is shown with air and electrolyte ducts removed for clarity. A hopper appears above the clad portion of the cell with a disk-shaped positive terminal.

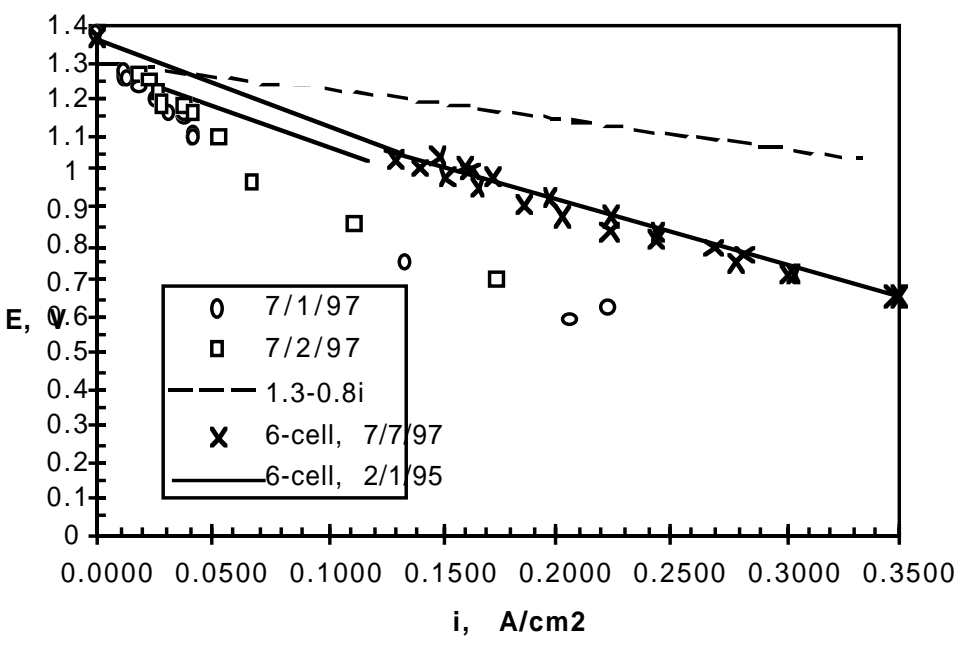

Fig. 3- Comparison of polarization (average, per unit cell) of current multicell design (x) with IR-free limits (dashed line) and with February 1995 data from bus test (broken line). Earlier tests of a single cell of the current design (open data points, 7/1/97 and 7/2/97) showed unexpectedly high resistance attributed to Faraday shielding from a dense anode current collector screen used in these tests.

Work performed under the auspices of the U.S. Department of Energy by the Lawrence Livermore National Laboratory under contract number W-7405-ENG-48.

\section{References}

1. John F. Cooper, Dennis Fleming, D. Hargrove, K. Peterman and R. Koopman, "A Refuelable Zinc/Air Battery for Fleet Electric Vehicle Propulsion," (Proc. of the 1995 SAE Future Transportation Technology Conference and Exposition, August 1995). Lawrence Livermore National Laboratory Report UCRL-JC-120308 April 25, 1995. *

2. John F. Cooper and Roger Krueger, "The zinc-air battery: alternative zinc fuel morphologies and cell behavior," Paper presented to the 12th Annual Advanced Battery Conference, Long Beach CA Jan 14-17 1997; UCRL-JC-125729, January 15, 1997. 


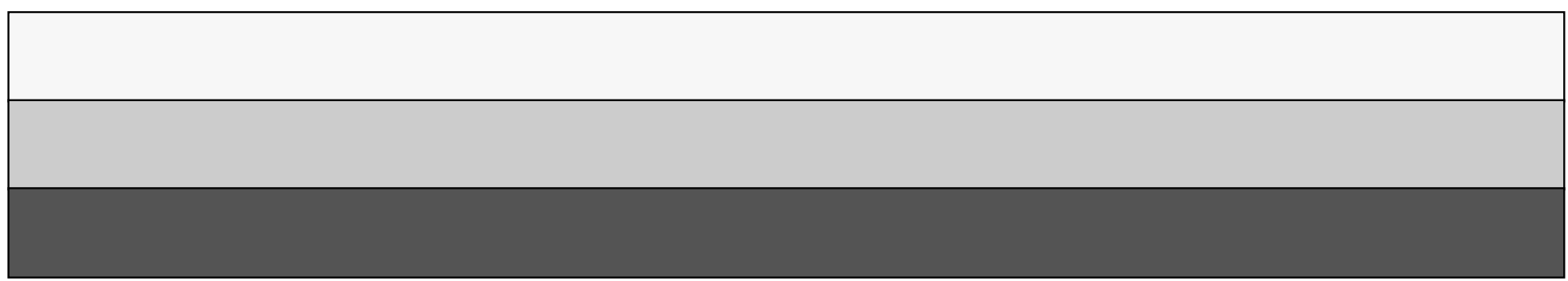

